Article

\title{
Rumphellaones B and C, New 4,5-Seco-Caryophyllane Sesquiterpenoids from Rumphella antipathies
}

Hsu-Ming Chung ${ }^{1, \dagger}$, Wei-Hsien Wang ${ }^{2,3, \dagger}$, Tsong-Long Hwang ${ }^{4}$, Jan-Jung Li ${ }^{2}$, Lee-Shing Fang ${ }^{5}$, Yang-Chang Wu ${ }^{6,7,8, *}$ and Ping-Jyun Sung ${ }^{2,3,7,9,10, *}$

1 Department of Applied Chemistry, National Pingtung University, Pingtung 900, Taiwan;

E-Mail: shiuanmin@mail.npue.edu.tw

2 National Museum of Marine Biology and Aquarium, Pingtung 944, Taiwan;

E-Mails:whw@nmmba.gov.tw (W.-H.W.); jj@nmmba.gov.tw (J.-J.L.)

3 Department of Marine Biotechnology and Resources and Asia-Pacific Ocean Research Center,

National Sun Yat-sen University, Kaohsiung 804, Taiwan

4 Graduate Institute of Natural Products, Chang Gung University, Taoyuan 333, Taiwan;

E-Mail: htl@mail.cgu.edu.tw

5 Department of Sport, Health and Leisure, Cheng Shiu University, Kaohsiung 833, Taiwan;

E-Mail: 1sfang@csu.edu.tw

6 School of Pharmacy, College of Pharmacy, China Medical University, Taichung 404, Taiwan

7 Chinese Medicine Research and Development Center, China Medical University Hospital, Taichung 404, Taiwan

8 Center for Molecular Medicine, China Medical University Hospital, Taichung 404, Taiwan

9 Institute of Marine Biology, Department of Life Science and Institute of Biotechnology, National Dong Hwa University, Pingtung 944, Taiwan

${ }^{10}$ Graduate Institute of Natural Products, Kaohsiung Medical University, Kaohsiung 807, Taiwan

$\dagger$ These authors contributed equally to this work.

* Authors to whom correspondence should be addressed;

E-Mails: yachwu@mail.cmu.edu.tw (Y.-C.W.); pjsung@nmmba.gov.tw (P.-J.S.);

Tel.: +886-4-220-57513 (Y.-C.W.); +886-8-882-5037 (P.-J.S.);

Fax: +886-4-220-60248 (Y.-C.W.); +886-8-882-5087 (P.-J.S.).

Received: 14 July 2014; in revised form: 11 August 2014 / Accepted: 11 August 2014 /

Published: 14 August 2014

Abstract: Two new 4,5-seco-caryophyllane sesquiterpenoids, rumphellaones B (1) and C (2), which were found to possess unprecedented $\gamma$-lactone moieties, were obtained from the 
gorgonian coral Rumphella antipathies. The structures of $\mathbf{1}$ and $\mathbf{2}$ were elucidated by spectroscopic methods and compound $\mathbf{2}$ was found to display modest inhibitory effects on the generation of superoxide anions and the release of elastase by human neutrophils at a concentration of $10 \mu \mathrm{g} / \mathrm{mL}$.

Keywords: Rumphella antipathies; rumphellaones B and C; caryophyllane-type sesquiterpenoid; anti-inflammatory activity

\section{Introduction}

The chemical constituents of gorgonian corals of the genus Rumphella, which are widely distributed in the subtropical and tropical waters of the Indo-Pacific Ocean have been investigated for ecological and medical uses [1-3]. As part of our ongoing investigation into the isolation of new substances from marine invertebrates collected in the waters of Taiwan, an intersection of the Kuroshio and Oyashio currents, the chemical constituents of an organic extract of the gorgonian coral Rumphella antipathies (Scheme 1) which displayed meaningful signals in NMR studies were studied. Previous chemical investigations on $R$. antipathies yielded a series of caryophyllane-type sesquiterpenoid analogues, including kobusone [4], isokobusone [5], rumphellolides A-I [6-9], and rumphellatins A-D [10-12], which mostly possess a bicyclo[7.2.0] carbon skeleton. Moreover, in an our previous study, the first 4,5-seco-caryophyllane derivative, rumphellaone A [13], was isolated from $R$. antipathies. In further studies on this interesting organism, two new 4,5-seco-caryophyllane derivatives, rumphellaones B (1) and C (2), were isolated. In this paper, we describe the isolation, structure determination and anti-inflammatory properties of compounds $\mathbf{1}$ and $\mathbf{2}$ (Scheme 1).

Scheme 1. The gorgonian coral Rumphella antipathies and the structures of rumphellaones B (1), C (2) and A (3).

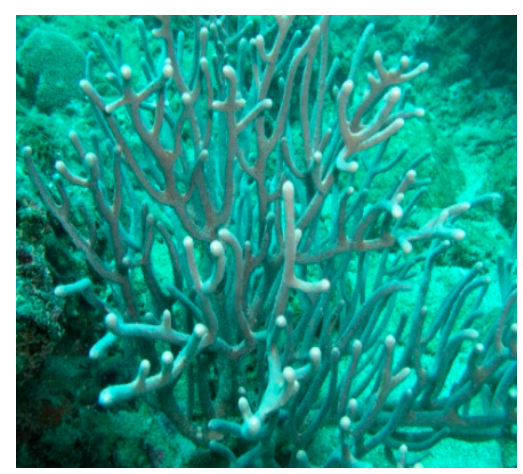

Rumphella antipathies

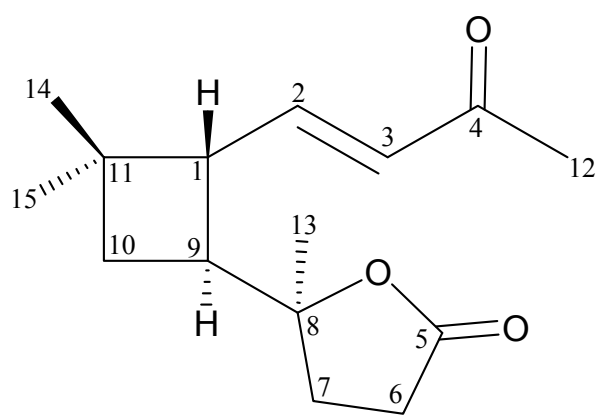

1

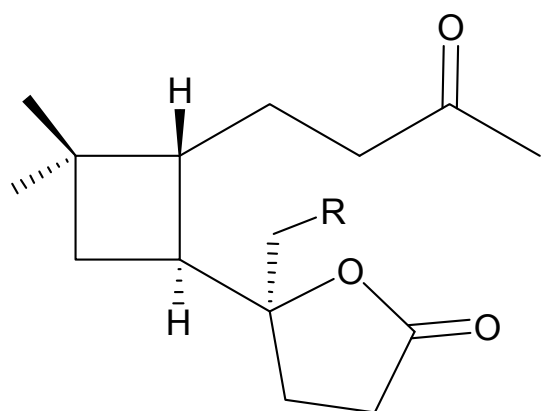

2: $\mathrm{R}=\mathrm{OH}, \mathbf{3}: \mathrm{R}=\mathrm{H}$

\section{Results and Discussion}

Rumphellaone B (1) was isolated as a colorless oil that gave a pseudomolecular ion $[\mathrm{M}-\mathrm{H}]^{+}$at $m / z$ 249.1493 in the HRESIMS, indicating the molecular formula $\mathrm{C}_{15} \mathrm{H}_{22} \mathrm{O}_{3}$ (calcd. for $\mathrm{C}_{15} \mathrm{H}_{21} \mathrm{O}_{3}, 249.1485$ ) implying five degrees of unsaturation. IR absorptions were observed at 1,767 and $1,712 \mathrm{~cm}^{-1}$, suggesting 
the presence of $\gamma$-lactone and $\alpha, \beta$-unsaturated ketone groups. The ${ }^{13} \mathrm{C}$-NMR and DEPT spectra of $\mathbf{1}$ (Table 1) showed that this compound has 15 carbons, including four methyls, three $\mathrm{sp}^{3}$ methylenes, two $\mathrm{sp}^{3}$ methines, two $\mathrm{sp}^{2}$ methines and four quaternary carbons (including an oxygenated quaternary carbon, an ester carbonyl and a ketone carbonyl). From the ${ }^{13} \mathrm{C}-\mathrm{NMR}$ data, three degrees of unsaturation were accounted for and $\mathbf{1}$ must thus be a compound with two rings. From the ${ }^{1} \mathrm{H}-{ }^{1} \mathrm{H}$ COSY experiment of 1 (Table 1 and Figure 1), it was possible to establish the spin systems that map out the proton sequences from $\mathrm{H}_{2}-10 / \mathrm{H}-9 / \mathrm{H}-1 / \mathrm{H}-2 / \mathrm{H}-3$ and $\mathrm{H}_{2}-6 / \mathrm{H}_{2}-7$, which were assembled with the assistance of an HMBC experiment (Table 1 and Figure 1). The HMBC correlations between protons and quaternary carbons of 1 , such as $\mathrm{H}-2, \mathrm{H}-3, \mathrm{H}_{3}-12 / \mathrm{C}-4 ; \mathrm{H}_{2}-6, \mathrm{H}_{2}-7 / \mathrm{C}-5 ; \mathrm{H}-1, \mathrm{H}_{2}-10, \mathrm{H}_{3}-13 / \mathrm{C}-8$; and $\mathrm{H}-1, \mathrm{H}_{2}-10, \mathrm{H}_{3}-14, \mathrm{H}_{3}-15 / \mathrm{C}-11$ permitted elucidation of the main carbon skeleton of 1 . The tertiary methyls at C-4 and C-8 were confirmed by the HMBC correlations between $\mathrm{H}_{3}-12 / \mathrm{C}-3$, -4 and $\mathrm{H}_{3}-13 / \mathrm{C}-7,-8,-9$, respectively. Moreover, two tertiary methyls at C-11 were elucidated by the HMBC correlations between $\mathrm{H}_{3}-14 / \mathrm{C}-1,-10,-11,-15$ and $\mathrm{H}_{3}-15 / \mathrm{C}-1,-10,-11,-14$. The linkage between the fragments cyclobutane and $\gamma$-lactone was established by the HMBC correlations between $\mathrm{H}-1$, $\mathrm{H}_{2}-10 / \mathrm{C}-8$ and $\mathrm{H}_{3}-13 / \mathrm{C}-9$. Based on the consideration of molecular formula, an oxygen atom had to be placed between the $\mathrm{C}-5$ carbonyl carbon $\left(\delta_{\mathrm{C}}\right.$ 176.7) and the $\mathrm{C}-8$ oxygenated quaternary carbon $\left(\delta_{\mathrm{C}} 86.6\right)$ to form a $\gamma$-lactone moiety.

Table 1. ${ }^{1} \mathrm{H}\left(400 \mathrm{MHz}, \mathrm{CDCl}_{3}\right)$ and ${ }^{13} \mathrm{C}\left(100 \mathrm{MHz}, \mathrm{CDCl}_{3}\right) \mathrm{NMR}$ data, ${ }^{1} \mathrm{H}-{ }^{1} \mathrm{H} \mathrm{COSY}$ and HMBC correlations for rumphellaone B (1).

\begin{tabular}{ccccc}
\hline Position & $\boldsymbol{\delta}_{\mathbf{H}}(\boldsymbol{J}$ in Hz $)$ & $\boldsymbol{\delta}_{\mathbf{C}}$, Multiple & ${ }^{1} \mathbf{H}-{ }^{1} \mathbf{H}$ COSY & HMBC \\
\hline 1 & $2.78 \mathrm{dd}(9.2,8.4)$ & $48.0, \mathrm{CH}$ & $\mathrm{H}-2, \mathrm{H}-9$ & $\mathrm{C}-2,-3,-8,-9,-11,-14,-15$ \\
2 & $6.77 \mathrm{dd}(16.0,8.4)$ & $147.1, \mathrm{CH}$ & $\mathrm{H}-1, \mathrm{H}-3$ & $\mathrm{C}-4,-9$ \\
3 & $6.09 \mathrm{~d}(16.0)$ & $131.4, \mathrm{CH}$ & $\mathrm{H}-2$ & $\mathrm{C}-1,-4$ \\
4 & & $198.1, \mathrm{C}$ & & \\
5 & & $176.7, \mathrm{C}$ & & $\mathrm{C}-5$ \\
6 & $2.51-2.68 \mathrm{~m}$ & $29.1, \mathrm{CH}_{2}$ & $\mathrm{H}_{2}-7$ & $\mathrm{C}-5,-6$ \\
7 & $1.85-2.02 \mathrm{~m}$ & $30.9, \mathrm{CH}_{2}$ & $\mathrm{H}_{2}-6$ & \\
8 & & $86.6, \mathrm{C}$ & & $\mathrm{C}-1,-2,-10$ \\
9 & $2.39 \mathrm{~m}$ & $43.0, \mathrm{CH}$ & $\mathrm{H}-1, \mathrm{H}_{2}-10$ & $\mathrm{C}-1,-8,-9,-11,-14,-15$ \\
10 & $1.51-1.70 \mathrm{~m}$ & $33.1, \mathrm{CH}_{2}$ & $\mathrm{H}-9$ & $\mathrm{C}-3,-4$ \\
11 & & $36.0, \mathrm{C}$ & & $\mathrm{C}-7,-8,-9$ \\
12 & $2.25 \mathrm{~s}$ & $27.4, \mathrm{CH}_{3}$ & & $\mathrm{C}-1,-10,-11,-15$ \\
13 & $1.25 \mathrm{~s}$ & $24.6, \mathrm{CH}_{3}$ & & $\mathrm{C}-1,-10,-11,-14$ \\
14 & $1.04 \mathrm{~s}$ & $23.8, \mathrm{CH}_{3}$ & & \\
15 & $1.10 \mathrm{~s}$ & $29.6, \mathrm{CH}_{3}$ & &
\end{tabular}

The relative configuration of $\mathbf{1}$ was established by an analysis of interactions that were found in the NOESY experiment (Figure 2) and by vicinal ${ }^{1} \mathrm{H}-{ }^{1} \mathrm{H}$ coupling constant analysis. Due to the $\alpha$-orientation of H-9, a large coupling constant was found between $\mathrm{H}-9$ and $\mathrm{H}-1 \quad(J=9.2 \mathrm{~Hz})$, indicating that $\mathrm{H}-1$ has a $\beta$-orientation. $\mathrm{H}-1$ showed a correlation with the tertiary methyl Me-15 suggesting that $\mathrm{H}-1$ and $\mathrm{H}_{3}-15$ are located on the same face. Me-13 showed an interaction with $\mathrm{H}-9$ and by comparison the NMR data of C- 8 oxygenated quaternary carbon $\left(\delta_{\mathrm{C}} 86.6\right)$ and Me-13 $\left(\delta_{\mathrm{H}} 1.25\right.$, $\left.3 \mathrm{H}, \mathrm{s} ; \delta_{\mathrm{C}} 24.6\right)$ with those of a similar analogue, rumphellaone A $(3)\left(\delta_{\mathrm{C}} 87.2, \mathrm{C}-8 ; \delta_{\mathrm{H}} 1.31,3 \mathrm{H}, \mathrm{s} ; \delta_{\mathrm{C}}\right.$ 
24.9, $\mathrm{CH}_{3}-13$ ) [13], indicating that $\mathrm{Me}-13$ was $\alpha$-oriented at $\mathrm{C}-8$. The trans geometry of the $\mathrm{C}-2 / 3$ double bond was indicated by a $16.0 \mathrm{~Hz}$ coupling constant between H-2 $\left(\delta_{\mathrm{H}} 6.77\right)$ and $\mathrm{H}-3\left(\delta_{\mathrm{H}} 6.09\right)$. Based on the above findings, the configurations of all chiarl carbons of 1 were assigned to be $1 R^{*}, 8 S^{*}$ and $9 S^{*}$.

Figure 1. Selective key ${ }^{1} \mathrm{H}-{ }^{1} \mathrm{H}$ COSY and $\mathrm{HMBC}$ correlations for $\mathbf{1}$.

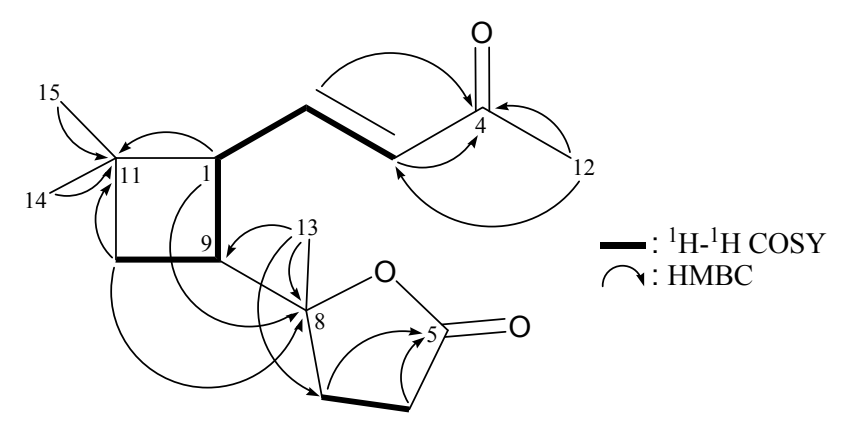

Figure 2. Selective key NOESY correlations for 1.

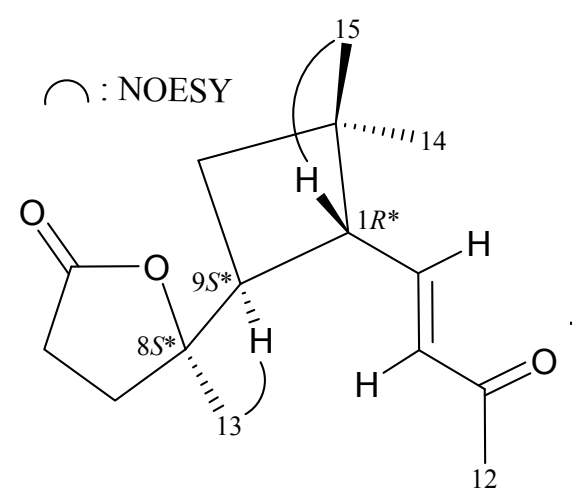

Rumphellaone C (2) was isolated as a colorless oil that gave a pseudomolecular ion $[\mathrm{M}+\mathrm{Na}]^{+}$at $m / z$ 291.1570 in the HRESIMS, indicating the molecular formula $\mathrm{C}_{15} \mathrm{H}_{24} \mathrm{O}_{4}$ (calcd. for $\mathrm{C}_{15} \mathrm{H}_{24} \mathrm{O}_{4} \mathrm{Na}$, 291.1572) and implying four degrees of unsaturation. IR absorptions were observed at 3,435, 1,763 and $1,714 \mathrm{~cm}^{-1}$, suggesting the presence of hydroxy, $\gamma$-lactone and ketone groups in 2 . The ${ }^{13} \mathrm{C}$-NMR and DEPT spectra showed that this compound has 15 carbons (Table 2), including three methyls, six methylenes (including an oxymethylene), two methines and four quaternary carbons (including an oxygenated quaternary carbon and two carbonyls). Thus, from the ${ }^{13} \mathrm{C}-\mathrm{NMR}$ data, two degrees of unsaturation was accounted for, and 2 must have two rings. The ${ }^{1} \mathrm{H}-\mathrm{NMR}$ spectrum of $\mathbf{2}$ showed that all three methyl groups are isolated. In addition, six pairs of aliphatic methylene protons and two aliphatic methine protons were observed in the ${ }^{1} \mathrm{H}-\mathrm{NMR}$ spectrum of $\mathbf{2}$ (Table 2). It was found that the spectral data (IR, ${ }^{1} \mathrm{H}$ and ${ }^{13} \mathrm{C}-\mathrm{NMR}$ ) of 2 were similar to those of a known analogue, rumphellaone $\mathrm{A}$ (3) [13]. However, the ${ }^{1} \mathrm{H}$ and ${ }^{13} \mathrm{C}-\mathrm{NMR}$ spectra revealed that the signals corresponding to the $\mathrm{C}-13$ methyl group in $\mathbf{2}$ disappeared and were replaced by those of an additional hydroxymethyl group. Thus, compound $\mathbf{2}$ was found to be the 13-hydroxy derivative of $\mathbf{3}$ with the structure as described by formula 2 . 
The in vitro anti-inflammatory effects of compounds $\mathbf{1}$ and $\mathbf{2}$ were examined and $\mathbf{2}$ displayed modestly inhibitory effects on the generation of superoxide anions (inhibition rate $=24.7 \%$ ) and the release of elastase (inhibition rate $=21.1 \%$ ) by human neutrophils in response to FMLP/CB at a concentration of $10 \mu \mathrm{g} / \mathrm{mL}$.

Table 2. ${ }^{1} \mathrm{H}\left(400 \mathrm{MHz}, \mathrm{CDCl}_{3}\right)$ and ${ }^{13} \mathrm{C}\left(100 \mathrm{MHz}, \mathrm{CDCl}_{3}\right) \mathrm{NMR}$ data, ${ }^{1} \mathrm{H}-{ }^{1} \mathrm{H}$ COSY and HMBC correlations for rumphellaone $\mathrm{C}(\mathbf{2})$.

\begin{tabular}{|c|c|c|c|c|}
\hline Position & $\delta_{\mathrm{H}}(J$ in $\mathrm{Hz})$ & $\delta_{\mathrm{C}}$, Multiple & ${ }^{1} \mathrm{H}-{ }^{1} \mathrm{H}$ COSY & HMBC \\
\hline 1 & $1.90 \mathrm{~m}$ & $44.0, \mathrm{CH}$ & $\mathrm{H}_{2}-2, \mathrm{H}-9$ & $C-10,-11,-15$ \\
\hline 2 & $1.62 \mathrm{~m}$ & $24.9, \mathrm{CH}_{2}$ & $\mathrm{H}-1, \mathrm{H}_{2}-3$ & $C-1,-3,-4,-9,-11$ \\
\hline 3 & $2.36 \mathrm{t}(7.2)$ & $41.8, \mathrm{CH}_{2}$ & $\mathrm{H}_{2}-2$ & $C-1,-2,-4$ \\
\hline 4 & & 208.6, C & & \\
\hline 5 & & 177.6, C & & \\
\hline \multirow[t]{2}{*}{6} & $2.54 \operatorname{ddd}(18.0,10.8,5.2)$ & 29.7, $\mathrm{CH}_{2}$ & $\mathrm{H}_{2}-7$ & $C-5,-7$ \\
\hline & $2.71 \mathrm{ddd}(18.0,10.8,7.6)$ & & & \\
\hline \multirow[t]{2}{*}{7} & $1.94 \operatorname{ddd}(14.2,10.8,7.6)$ & 25.6, $\mathrm{CH}_{2}$ & $\mathrm{H}_{2}-6$ & $C-5,-8,-9,-13$ \\
\hline & $2.20 \mathrm{ddd}(14.2,10.8,5.2)$ & & & \\
\hline 8 & & $89.5, \mathrm{C}$ & & \\
\hline 9 & $2.12 \mathrm{ddd}(10.0,10.0,9.6)$ & $40.2, \mathrm{CH}$ & $\mathrm{H}-1, \mathrm{H}_{2}-10$ & n. o. ${ }^{a}$ \\
\hline \multirow[t]{2}{*}{10} & $1.43 \mathrm{dd}(10.4,10.0)$ & $33.0, \mathrm{CH}_{2}$ & H-9 & C-1, $-8,-9,-11,-14,-15$ \\
\hline & $1.57 \mathrm{dd}(10.4,9.6)$ & & & \\
\hline 11 & & $33.5, \mathrm{C}$ & & \\
\hline 12 & $2.12 \mathrm{~s}$ & $30.0, \mathrm{CH}_{3}$ & & $C-3,-4$ \\
\hline \multirow[t]{2}{*}{13} & $3.43 \mathrm{~d}(11.6)$ & 66.6, $\mathrm{CH}_{2}$ & & $C-7,-8$ \\
\hline & $3.73 \mathrm{~d}(11.6)$ & & & \\
\hline 14 & $1.03 \mathrm{~s}$ & $22.5, \mathrm{CH}_{3}$ & & $C-1,-10,-11,-15$ \\
\hline 15 & $1.07 \mathrm{~s}$ & $30.8, \mathrm{CH}_{3}$ & & $C-1,-10,-11,-14$ \\
\hline
\end{tabular}

\section{Experimental Section}

\subsection{General Experimental Procedures}

Optical rotation values were measured with a Jasco P-1010 digital polarimeter (Japan Spectroscopic Corporation, Tokyo, Japan). IR spectra were obtained on a Varian Diglab FTS 1000 FT-IR spectrophotometer (Varian Inc., Palo Alto, CA, USA); peaks are reported in $\mathrm{cm}^{-1}$. NMR spectra were recorded on a Varian Mercury Plus 400 NMR spectrometer (Varian Inc.) using the residual $\mathrm{CHCl}_{3}$ signal $\left(\delta_{\mathrm{H}} 7.26 \mathrm{ppm}\right)$ as the internal standard for ${ }^{1} \mathrm{H}-\mathrm{NMR}$ and $\mathrm{CDCl}_{3}\left(\delta_{\mathrm{C}} 77.1 \mathrm{ppm}\right)$ for ${ }^{13} \mathrm{C}-\mathrm{NMR}$. Coupling constants $(J)$ are given in Hz. ESIMS and HRESIMS were recorded using a Bruker 7 Tesla solariX FTMS system (Bruker, Bremen, Germany). Column chromatography was performed on silica gel (230-400 mesh, Merck, Darmstadt, Germany). TLC was carried out on precoated Kieselgel $60 \mathrm{~F}_{254}$ ( $0.25 \mathrm{~mm}$, Merck); spots were visualized by spraying with $10 \% \mathrm{H}_{2} \mathrm{SO}_{4}$ solution followed by heating. Normal-phase HPLC (NP-HPLC) was performed using a system comprised of a Hitachi L-7110 pump (Hitachi Ltd., Tokyo, Japan), a Hitachi L-7455 photodiode array detector (Hitachi Ltd.) and a Rheodyne 7725 injection port (Rheodyne LLC, Rohnert Park, CA, USA). A semi-preparative 
normal-phase column (Hibar $250 \times 10 \mathrm{~mm}$, LiChrospher Si 60, $5 \mu \mathrm{m}$, Merck, Darmstadt, Germany) was used for HPLC.

\subsection{Animal Material}

Specimens of the gorgonian coral Rumphella antipathies (Nutting) were collected by hand using scuba equipment off the coast of Pingtung, Southern Taiwan. A voucher specimen (specimen No. NMMBA-TWGC-010) was deposited in the National Museum of Marine Biology and Aquarium, Taiwan.

\subsection{Extraction and Isolation}

Sliced bodies of the gorgonian $R$. antipathies (wet weight $402 \mathrm{~g}$, dry weight $144 \mathrm{~g}$ ) are extracted with a mixture of methanol $(\mathrm{MeOH})$ and dichloromethane $\left(\mathrm{CH}_{2} \mathrm{Cl}_{2}\right)(1: 1)$ at room temperature. The extract was partitioned between ethyl acetate (EtOAc) and $\mathrm{H}_{2} \mathrm{O}$ and the EtOAc layer was subjected to silica gel and eluted using $n$-hexane/EtOAc (stepwise, 25:1-pure EtOAc) to yield 29 fractions. Every fraction was checked using the ${ }^{1} \mathrm{H}-\mathrm{NMR}$ spectra. Fractions 21 and 27 were re-purified by normal phase HPLC (NP-HPLC) using a mixture of $n$-hexane and acetone as the mobile phase to afford 1 (5.0 $\mathrm{mg}, 3: 1)$ and $2(3.4 \mathrm{mg}, 2: 1)$, respectively.

Rumphellaone $B(\mathbf{1})$ : Colorless oil; $[\alpha]_{\mathrm{D}}^{25}+18\left(c \quad 0.25, \mathrm{CHCl}_{3}\right)$; IR (neat) $v_{\max } 1,767,1,712 \mathrm{~cm}^{-1}$; ${ }^{1} \mathrm{H}-\mathrm{NMR}\left(\mathrm{CDCl}_{3}, 400 \mathrm{MHz}\right)$ and ${ }^{13} \mathrm{C}-\mathrm{NMR}\left(\mathrm{CDCl}_{3}, 100 \mathrm{MHz}\right)$ data, see Table 1; ESIMS $\mathrm{m} / z 249$ $[\mathrm{M}-\mathrm{H}]^{+}$; HRESIMS $m / z 249.1493$ (calcd. for $\mathrm{C}_{15} \mathrm{H}_{22} \mathrm{O}_{3}-\mathrm{H}, 249.1485$ ).

Rumphellaone $C$ (2): Colorless oil; $[\alpha]_{\mathrm{D}}^{25}-8\left(c 0.18, \mathrm{CHCl}_{3}\right)$; IR (neat) $v_{\max } 3,435,1,763,1,714 \mathrm{~cm}^{-1}$; ${ }^{1} \mathrm{H}-\mathrm{NMR}\left(\mathrm{CDCl}_{3}, 400 \mathrm{MHz}\right)$ and ${ }^{13} \mathrm{C}-\mathrm{NMR}\left(\mathrm{CDCl}_{3}, 100 \mathrm{MHz}\right)$ data: see Table 2; ESIMS $\mathrm{m} / z 291$ $[\mathrm{M}+\mathrm{Na}]^{+}$; HRESIMS $m / z 291.1570$ (calcd. for $\mathrm{C}_{15} \mathrm{H}_{24} \mathrm{O}_{4}+\mathrm{Na}, 291.1572$ ).

\subsection{Generation of Superoxide Anions and Release of Elastase by Human Neutrophils}

Human neutrophils were obtained by means of dextran sedimentation and Ficoll centrifugation. Measurements of superoxide anion generation and elastase release were carried out according to previously described procedures [14,15]. Briefly, superoxide anion production was assayed by monitoring the superoxide dismutase-inhibitable reduction of ferricytochrome $c$. Elastase release experiments were performed using $\mathrm{MeO}-\mathrm{Suc}-\mathrm{Ala}$-Ala-Pro-Valp-nitroanilide as the elastase substrate. In the in vitro anti-inflammatory bioassay, the inhibitory effects on the generation of superoxide anion and the release of elastase by activated neutrophils were used as indicators. For significant activity of pure compounds, an inhibition rate $\geq 50 \%$ is required (inhibition rate $\leq 10 \%$, not active; $20 \% \geq$ inhibition rate $\geq 10 \%$, weakly anti-inflammatory; $50 \% \geq$ inhibition rate $\geq 20 \%$, modestly anti-inflammatory).

\section{Conclusions}

The gorgonian coral $R$. antipathies, collected off the waters of Taiwan, has proven to be a rich source of caryophyllane- and clovane-type sesquiterpenoids. In our continuing investigation on the chemical constituents of $R$. antipathies, two new 4,5-secocaryophyllane derivatives, rumphellaones B 
(1) and C (2), were isolated. It is noteworthy to mention that metabolites $\mathbf{1}$ and $\mathbf{2}$ represent the second and third 4,5-secocaryophyllane derivative containing a $\gamma$-lactone moiety, respectively, and compound 2 was found to display modestly inhibitory effects on the generation of superoxide anions and the release of elastase by human neutrophils.

\section{Acknowledgments}

This research was supported by grants from the National Museum of Marine Biology and Aquarium; National Dong Hwa University; Asia-Pacific Ocean Research Center, National Sun Yat-sen University; the Ministry of Science and Technology (Grant No. NSC101-2320-B-291-001-MY3 and MOST 103-2325-B-291-001); and China Medical University under the Aim for Top University Plan of the Ministry of Education, Taiwan, awarded to Y.-C.W and P.-J.S.

\section{Author Contributions}

Yang-Chang Wu and Ping-Jyun Sung designed the whole experiment and contributed to manuscript preparation; Hsu-Ming Chung and Wei-Hsien Wang researched data and wrote the manuscript; Tsong-Long Hwang, Jan-Jung Li, and Lee-Shing Fang analyzed the data and performed data acquisition.

\section{Conflicts of Interest}

The authors declare no conflict of interest.

\section{References}

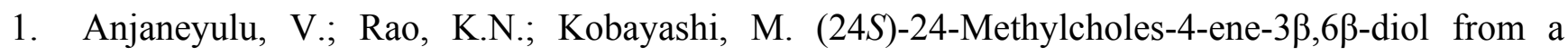
gorgonian (Rumphella. aggregata) of the Andaman and the Nicobar Islands. Indian J. Chem. 1995, 34B, 78-80.

2. Puglisi, M.P.; Paul, V.J.; Biggs, J.; Slattery, M. Co-occurrence of chemical and structural defenses in the gorgonian corals of Guam. Mar. Ecol. Prog. Ser. 2002, 239, 105-114.

3. Nourry, M.; Urvois, P.-A.; Tomasoni, C.; Biard, J.F.; Verbist, J.F.; Roussakis, C. Antiproliferative effects of a product isolated from the gorgonian Rumphella. aggregata. Anticancer Res. 1999, 19, 1881-1885.

4. Chuang, L.-F.; Fan, T.-Y.; Li, J.-J.; Sung, P.-J. Kobusone: occurrence of a norsesquiterpenoid in the gorgonian coral Rumphella. antipathies (Gorgoniidae). Biochem. Syst. Ecol. 2007, 35, 470-471.

5. Chuang, L.-F.; Fan, T.-Y.; Li, J.-J.; Kuo, J.; Fang, L.-S.; Wang, W.-H.; Sung, P.-J. Isokobusone, a caryophyllane-type norsesquiterpenoid from the gorgonian coral Rumphella antipathies (Gorgoniidae). Platax 2007, 2007, 61-67.

6. Sung, P.-J.; Chuang, L.-F.; Kuo, J.; Chen, J.-J.; Fan, T.-Y.; Li, J.-J.; Fang, L.-S.; Wang, W.-H. Rumphellolides A-F, six new caryophyllane-related derivatives from the Formosan gorgonian coral Rumphella antipathies. Chem. Pharm. Bull. 2007, 55, 1296-1301. 
7. Sung, P.-J.; Chuang, L.-F.; Fan, T.-Y.; Chou, H.-N.; Kuo, J.; Fang, L.-S.; Wang, W.-H. Rumphellolide G, a new caryophyllane-type tetrahydropyran norsesquiterpenoid from the gorgonian coral Rumphella antipathies (Gorgoniidae). Chem. Lett. 2007, 36, 1322-1323.

8. Hwang, T.-L.; Su, Y.-D.; Hu, W.-P.; Chuang, L.-F.; Sung, P.-J. Rumphellolide H, a new natural caryophyllane from the gorgonian Rumphella antipathies. Heterocycles 2009, 78, 1563-1567.

9. Sung, P.-J.; Su, Y.-D.; Hwang, T.-L.; Chuang, L.-F.; Chung, H.-M.; Chen, J.-J.; Li, J.-J.; Fang, L.-S.; Wang, W.-H. Rumphellolide I, a novel caryophyllane-related tetrahydropyran norsesquiterpenoid from gorgonian coral Rumphella antipathies. Chem. Lett. 2009, 38, 282-283.

10. Sung, P.-J.; Chuang, L.-F.; Kuo, J.; Fan, T.-Y.; Hu, W.-P. Rumphellatin A, the first chloride-containing caryophyllane-type norsesquiterpenoid from Rumphella antipathies. Tetrahedron Lett. 2007, 48, 3987-3989.

11. Sung, P.-J.; Chuang, L.-F.; Hu, W.-P. Rumphellatins B and C, two new caryophyllane-type hemiketal norsesquiterpenoids from the Formosan gorgonian coral Rumphella antipathies. Bull. Chem. Soc. Jpn. 2007, 80, 2395-2399.

12. Sung, P.-J.; Su, Y.-D.; Hwang, T.-L.; Chuang, L.-F.; Chen, J.-J.; Li, J.-J.; Fang, L.-S.; Wang, W.-H. Rumphellatin D, a novel chlorinated caryophyllane from gorgonian coral Rumphella antipathies. Chem. Lett. 2008, 37, 1244-1245.

13. Chung, H.-M.; Chen, Y.-H.; Lin, M.-R.; Su, J.-H.; Wang, W.-H.; Sung, P.-J. Rumphellaone A, a novel caryophyllane-related derivative from the gorgonian coral Rumphella antipathies. Tetrahedron Lett. 2010, 51, 6025-6027.

14. Yang, S.-C.; Chung, P.-J.; Ho, C.-M.; Kuo, C.-Y.; Hung, M.-F.; Huang, Y.-T.; Chang, W.-Y.; Chang, Y.-W.; Chan, K.-H.; Hwang, T.-L. Propofol inhibits superoxide production, elastase release, and chemotaxis in formyl peptide-activated human neutrophils by blocking formyl peptide receptor 1. J. Immunol. 2013, 190, 6511-6519.

15. Yu, H.-P.; Hsieh, P.-W.; Chang, Y.-J.; Chung, P.-J.; Kuo, L.-M.; Hwang, T.-L. 2-(2-Fluorobenzamido)benzoate ethyl ester (EFB-1) inhibits superoxide production by human neutrophils and attenuates hemorrhagic shock-induced organ dysfunction in rats. Free Radic. Biol. Med. 2011, 50, 1737-1748.

Sample Availability: Samples of the compounds are not available from the authors.

(C) 2014 by the authors; licensee MDPI, Basel, Switzerland. This article is an open access article distributed under the terms and conditions of the Creative Commons Attribution license (http://creativecommons.org/licenses/by/3.0/). 